\title{
Redaksioneel
}

\section{Professor JAAA Stoop emeriteer}

Prof JAAA Stoop het op 30 September 1985 sy sestigste verjaarsdag gevier en in dieselfde jaar as professor in Kerkgeskiedenis aan die Universiteit van Suid-Afrika geëmeriteer. Studente, vriende en kollegas van prof Stoop het onder redaksie van C Landman en DP Whitelaw 'n huldigingsbundel uitgegee. Die titel van die publikasie is: Oorspronge in oënskou: Opstelle oor die vroeë kerk ter ere van JAAA Stoop op sy sestigste verjaardag. Dié bundel opstelle word in die onderhawige aflewering van die Hervormde Teologiese Studies geresenseer. Prof AD Pont, Kerkhistorikus van die Universiteit van Pretoria en redaksielid van die Hervormde Teologiese Studies, vermeld in die resensie dat prof Stoop ' $n$ besondere bydrae tot die vak Kerkgeskiedenis in Suid-Afrika gelewer het en dat dit ' $n$ voldoening is om te weet dat daar navorsers is wat hierdie bydraes rakende die geskiedenis en standpunte van die vroeë kerk en sy woordvoerders sal voortsit. In Hervormde geledere het die Ou-Testamentikus van die Universiteit van Suid-Afrika, prof JA Loader, 'n DTh-proefskrif, getitel Die etiese Ou-Testamentici in Nederland tussen 1870 en 1914, onder promotorskap van prof Stoop in 1984 voltooi. 'n Ander promovendus van prof Stoop, prof JH le Roux, predikant van die Ned Geref Kerk en insgelyks Ou-Testamentikus van die Universiteit van Suid-Afrika, sit in bovermelde huldigingsbundel prof Stoop se akademiese werkwyse soos volg uiteen: "n Deeglike studie van die bron in verskillende teksuitgawes word eers gemaak, na onderlinge vergelyking word op die regte teks besluit (soms skep hy sy eie werkteks), hierna word 'n eie vertaling gemaak, 'n eie selfstandige interpretasie gevorm wat met ander antieke en moderne skrywers vergelyk word en dan eers word 'n artikel geskryf.' Iets hiervan word gesien in die artikel van prof Willem S Vorster, Hoof van die Instituut vir Teologiese Navorsing aan die Universiteit van Suid-Afrika, wat in die onderhawige aflewering van die Hervormde Teologiese Studies gepubliseer word. Die artikel, getitel 'Die brief aan Rheginos: Oor geloof en rede en die opstanding', is geskryf na aanleiding van gaslesings wat prof Vorster aan die Fakulteit Teologie van die Nederduitsch Hervormde Kerk, Universiteit van Pretoria, op 20 Augustus 1985 gelewer het. Hy dra sy artikel uit erkentlikheid aan prof Stoop op. Die Hervormde Teologiese Studies het genoeë om hierdie artikel te publiseer en 
betuig daarmee saam ook sy erkentlikheid aan prof Stoop en aan die akademiese staanplek wat hy ingeneem het.

Professor Jan Adriaan Albertus Abraham Stoop se skoolopleiding het geskied aan onderskeidelik die Laerskool Sandspruit en die Hoërskool Volksrust. In 1945 behaal hy sy BA-graad aan die Universiteit van Pretoria met as hoofvakke Grieks, Latyn en Hebreeus. In 1948 word die BD-graad aan die Fakulteit Teologie (Afdeling A), Universiteit van Pretoria en in 1958 die Dr Theol-graad aan die Rijksuniversiteit, Leiden behaal. Sy BA-, BD- en Dr Theol-grade word almal met lof geslaag. Sy doktorale proefskrif, getitel Die 'deificatio hominis' in die 'sermones' en 'epistulae' van Augustinus, word onder promotorskap van prof JN Bakhuizen van den Brink voltooi. Vanaf Oktober 1952 tot November 1956 is hy predikant van die Hervormde Gemeente Benoni en vanaf November 1956 tot Oktober 1966 predikant van die Hervormde Gemeente Brixton. Na aanleiding van die Cottesloe-beraad van die Wêreldraad van Kerke in 1960 kom hy in konflik met die kerkleiding van die Nederduitsch Hervormde Kerk van Afrika. Hy bedank in 1967 as predikant van die Hervormde Kerk, maar word weer in 1974 in die predikantekorps opgeneem en wel as predikant van die Hervormde $\mathrm{Ge}$ meente Oosmoot. Sedert Oktober 1966 is hy hoogleraar in Kerkgeskiedenis aan die Fakulteit Teologie van die Universiteit van Suid-Afrika. Sy professorale intreerede wat in 1967 gelewer is,. was getitel 'Bybelse uitgangspunte in die Kerkbegrip van Cyprianus'. Onder prof Stoop se publikasies is 'n sestal artikels in die Hervormde Teologiese Studies gepubliseer, te wete:

Die regverdigingsleer van kardinaal Contarini. HTS 8, 63-79.

Geskiedenis van die kerk van Culemborg in die eerste helfte van die 17de eeu. HTS 8, 115-125.

'n Ondersoek na die paastees by Augustinus. HTS 8, 138-147.

Oor die metode van ons kerkgeskiedskrywing en oor die kritiek daarop. HTS 9/3 \& 4, 282-287.

'n Belangrike dokument uit die jaar 1866. HTS 9/3 \& 4, 290-292.

Buiten die kerk geen heil: 'n Aspek van die kerkbegrip van Augustinus. HTS 11/2, 73-86. 